\title{
Interactive Museum Activities That Provide Venues for Innovation: Case Studies from the Lake Biwa Museum
}

\author{
Taisuke Ohtsuka
}

\begin{abstract}
How to define and construct a better relationship of coexistence between humans and nature through interactive museum activities is discussed based on the experiences of Lake Biwa Museum, Shiga, Japan. A better relationship cannot be determined objectively, and there is no justification for imposing one person's subjective good on others. So the museum has avoided expressions that imply value judgments. Experience-learning programs and interaction using staff communicators in the exhibition rooms may have helped visitors to conceive the formation of a better relationship, but appear to have done little toward arriving at mutual agreement or understanding. Workshops may be an effective means of exploring conceptual agreement and understanding among various people. Although our exploration toward mutually intelligible concepts of a better relationship is still at a quite primitive stage, some concepts such as sustainability appear to have been accepted by most residents of Shiga Prefecture. Thus, the Restoration of Fish Breeding in Paddy Fields project is analyzed as a social innovation generated by collaborative and interactive activities in which the museum has engaged. The original idea behind this project was advanced by a researcher of the museum who learned much about local experiences from farmers around Lake Biwa. The cooperative response of the prefectural government and local communities to the museum's suggestion appears to be based on rich social capital. Although the museum's researchers contributed no more than the idea and some related knowledge, other actors such as farmers, prefectural agencies, and researchers in other research institutes organized and advanced the project. The museum is still engaged to the extent of studying the project's effects or consequences, connecting researchers to the regions involved, and providing project-support participant events. We hope that further innovation along these lines will contribute to a "better relationship of coexistence between humans and lakes."
\end{abstract}

\footnotetext{
T. Ohtsuka ( $\square)$

Lake Biwa Museum, Oroshimo 1091, Kusatsu, Shiga 525-0001, Japan

e-mail: ohtsuka@lbm.go.jp 


\section{Introduction}

Museums must organize their activities in accordance with their own philosophies or missions. Nowadays, many Japanese museums set their own direction to construct better social and/or social-natural relationships. For instance, the mission of the Ibaraki Nature Museum is to "enhance harmonic coexistence of humans with nature, and promoting the amenity of cultural life." The Museum of Nature and Human Activities, Hyogo has a basic philosophy of "harmonious coexistence of nature and humans." The basic philosophy of the Lake Biwa Museum is "better relationship of coexistence between humans and lakes." They all aim at the betterment of coexistent relationships of humans with nature. This implies that the current state of these relationships is recognized as neither harmonious nor satisfactory. In other words, these museums seek to foster more sustainable and nature-friendly local societies. The following two problems arise, however, in attempting to organize practical activities that support such a philosophy or mission.

- How are better relationships defined?

- How can better relationships be realized?

In the present report, I will try to answer these two questions based on the experience of the Lake Biwa Museum; it is a prefectural museum of Shiga, $80 \%$ of whose total area is occupied by the catchment of Lake Biwa.

\section{How Are Better Relationships Determined?}

Naturally, within the philosophy of the Lake Biwa Museum, a "better relationship of coexistence between humans and lakes" cannot be defined objectively, because the concept is rooted in value judgments. Although scientific knowledge can contribute to the judgments, it cannot generate a sense of value by itself directly. Moreover, scientific activities are now generally regarded as model-building in a search for better explanation or predictive performance. Such models are not necessarily based on naïve realism, i.e., the belief that we can perceive the objective world directly.

There is no justification for imposing one person's subjective "good" on others. Such "good," however, can be imposed by an authority and/or power. An example of imposed value is displayed in the declaration formulated by Shiga Prefecture (2000) as a part of its Mother Lake Plan 21 concerning the Lake Biwa Comprehensive Development Plan launched in 1972 as a national program and concluded in 1997; this declaration stated that the "plan succeeded in providing a more effective utilization of the water resources of the lake and in significantly reducing flood damage," without critical remarks. Meanwhile, not a few people had opposed this development plan, mainly because they believed it would cause the destruction of the lake environment, and indeed, some negative effects on Lake Biwa's ecosystem have 
been reported (e.g., Nakanishi and Sekino 1997; Ohtsuka et al. 1996). Therefore, the conclusion that the development was "good" for people is imposed or, at least, one-sided. Mother Lake Plan 21 also states that "we must make the transition from the modern way of life based on mass production and consumption to one that is in harmony with the environment and is based on a symbiosis of humans and nature." Even within the same declaration, the standard of value appears to have largely shifted away from appreciation of the development noted above. It is still the case, however, that the values are imposed on people.

From its inception, the Lake Biwa Museum has studiously avoided the use of value-judgment expressions regarding a "better relationship of coexistence between humans and lakes." Nunotani (2014) explained the reason as follows: "Social problems arise depending on the social situations of the age, and naturally, their evaluations also change in successive periods. Therefore, our museum will provide people with information for thinking about such problems instead of making evaluations." This attitude has been consistently implemented by the museum in its exhibitions and other activities. Although the museum does not impose any concepts of values on people, there is also little evidence that its activities contribute much to consensusbuilding on its theme of better coexistence. There may be two different reasons for this. One is that the visitors themselves often expect or require a museum to present value judgments on the topics covered by the exhibits instead of thinking by themselves. Such users may feel that making their own value judgments is difficult. Another is the lack of a consensus-building process. Even if the users could construct concepts of values by themselves, making such concepts mutually agreeable or even intelligible is not guaranteed.

Kada (2001) argued for a strategy of translating knowledge into social action. It needs at least two steps, the first of which is personal experience, i.e., experiencing something directly and finding its meaning in one's own life. The second is shared social experiences, i.e., personal experiences that are shared in and supported by communities. Interactive museum activities are presumably effective for learning by experience. In particular, as far as the participants are constructing experiential learning occurring in a museum, it should to a great extent contribute to this process. The Lake Biwa Museum devised a new system to enhance the experiences of visitors when it opened in 1996. It is based on a group of communicators in the exhibition rooms who are now called Tenji-koryu-in. They communicate with visitors directly and/or mediate the interaction of visitors with the exhibitions. An effective way to conduct such mediation is to listen to the experiences of the visitors related to the exhibition context (Fig. 1). This helps connect the exhibition contents with the visitor's own experiences and promotes reconstruction of the experiences, a process called Jibun-ka or "personalization" by Yukiko Kada. Such experiences may also expand common understanding and thus contribute to the construction of mutual agreement or understanding. Personal and internalized experiences are necessary for this, but are not in themselves a sufficient basis for mutual agreement or understanding. Doxastic conflict is often encountered even among people educated through similar experiences. Value relativism can prevent immediate conflicts and the consequent decrease in motivation, but also mutual agreement and understanding. 

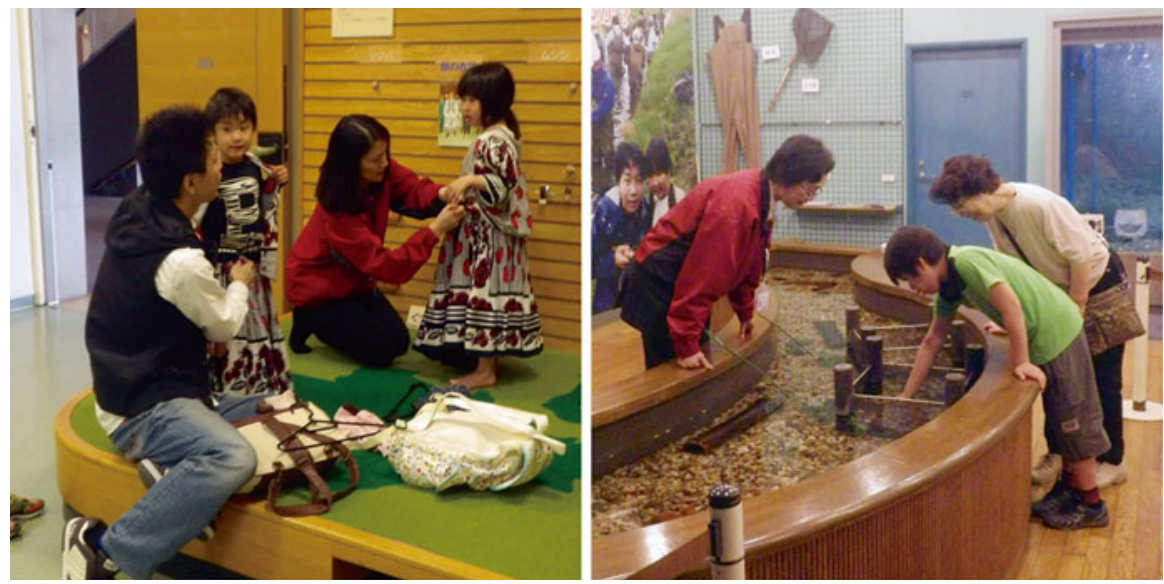

Fig. 1 Activities of communicators called Tenji-koryu-in

One possible approach to overcoming both doxastic conflict and value relativism is to examine the interests or motivations that underlie the value judgments. If the differences in the interests or motivations that serve as a basis of concept formation become clear, different concepts of values will become mutually understandable. Another approach is the organization of joint activities among diverse members or groups. Common experiences in such activities can form a common concept of values. In addition, contradictions between different concepts of values in collaborative activities possibly serve as a driving force in constructing innovative concepts (Engeström 1987; Engeström 2008).

Workshops may be a good avenue for exploring routes toward mutually intelligible or understandable concepts, because they can be organized so as to provide common experiences, to explore the underlying interests or motivations of each concept, and also to create dialectical discussion seeking innovative ideas or concepts. The Lake Biwa Museum, regrettably, has not organized such a workshop, but a series of annual workshops with similar aims has been organized by the Mother Lake Forum founded in 2012. These are called "Biwa-Comi Meetings" where "Comi" denotes community, communication, and commitment. The theme of each workshop is set by the committee. Various actors involved in the Lake Biwa catchment area discuss potential measures towards a better future for the lake. Interests, motivations, and problems are shared on the basis of mutual respect for different situations, experiences, and concepts. The workshops are not focused on agreements or conclusions, but give weight to shared interests, motivations, and problems. They aim to be a venue for finding mutually different or common concepts and for considering what each of the participants can do for the lake (http://mlf. shiga.jp/biwacomi). This practice appears to be improving year by year, and they thus stand far ahead of the Lake Biwa Museum. On the other hand, one must beware that such a practice comes to work as a control system for governmentality, i.e., a measure whereby governments try to produce citizens best suited to fulfill those 
governments' policies. The concepts, methods, and achievements of the "Biwa-Comi Meetings" need to be evolved critically, and new interactive museum activities not based on predetermined public policies should be constructed.

\section{How Can Better Relationships Be Achieved?}

As is discussed above, our efforts to arrive at a mutual agreement on, or understanding of, a "better relationship of coexistence between humans and lakes" is at a rather primitive stage. Nevertheless, some consensus among most regional actors has surely been found. For instance, a public opinion poll in Shiga Prefecture found that the local political topics ranked as the top three in terms of satisfaction level are "environmental arrangements that enable experiences of nature in our own backyard," "food security," and "maintenance of beautiful rural landscapes and green forests" (Shiga Prefecture 2014). This indicates that many residents regard the satisfaction with these as "good" and the related political measures as having been successfully worked out. Interestingly, they are all deeply associated with sustainable relationships between humans and nature in the Lake Biwa watershed. Therefore, it seems that the concept of sustainability can be accepted as a common "good" by most residents in Shiga Prefecture.

Aspirations for sustainability usually come from the recognition that it has been impaired. Many of us may feel that nature has retreated from our living areas, food security has been threatened, and the landscapes around farming and mountain villages have deteriorated, at least that such was the case in the past. Such experiences direct us to regenerating a sustainable relationship between humans and nature. Because such regeneration cannot be a simple restoration to the original state, it requires exploratory trials and social innovations, i.e., new strategies, concepts, ideas, and organizations that meet social needs. With this in mind, I will now introduce and analyze a case in which the Lake Biwa Museum contributed to a social activity aimed at regenerating a sustainable relationship with Lake Biwa.

In 2001, Shiga Prefecture started its "Sakana-no-yurikago-suiden" project, that is, "Restoration of Fish Breeding in Paddy Fields," around Lake Biwa. This project aims at rural environmental improvement by encouraging the resumption of fish migration between rice paddies and Lake Biwa. Land consolidation programs executed between the 1960s and 1980s raised the level of the rice paddies, and therefore generated considerable vertical drops (usually more than a meter) between the rice paddies and the water surface of the drainage canals. As a consequence, it became impossible for fish to enter the paddies for spawning. To remedy this situation, participating rural communities usually set fish-ladder cascades that work by elevating the water level of the upper reaches of a drainage canal through the installation of a series of successively higher flashboards; this sort of installation enables fish to enter the paddies adjacent to the canal by way of their drains (Fig. 2). By 2011, this program had expanded to about $1.2 \mathrm{~km}^{2}$ of paddy fields (Ohtsuka 2014). 


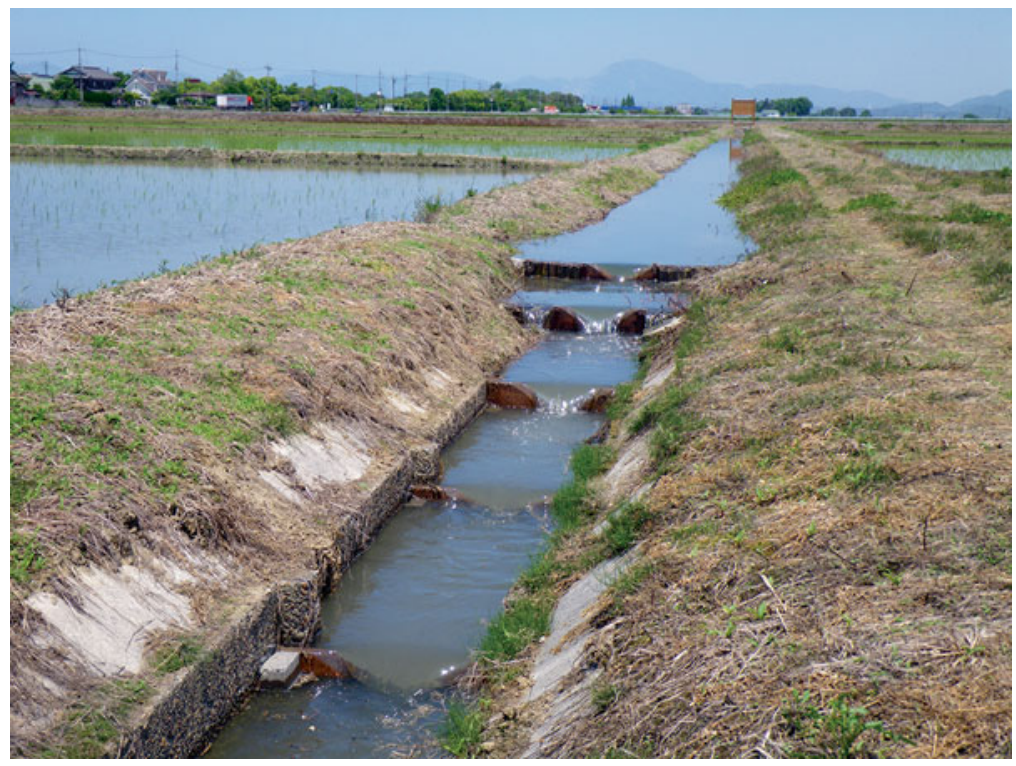

Fig. 2 A fish-ladder cascade set in a drainage canal (ㄷ Shigefumi Kanao)

The "Sakana-no-yurikago-suiden" project was originally inspired by the results of a comprehensive research program on paddy fields conducted by the Lake Biwa Museum from 1996 to 1998. In this collaborative study, some researchers learned from rice farmers that many fish used to spawn in rice paddies (Kada 2000; Yasumuro 2000). The most surprising story concerned the uojima, or fish island, phenomenon: during the rainy season in early summer, vast numbers of fish often invaded the paddy fields around Lake Biwa to spawn there, agglomerating to make an "island" (Kada 2000). After the research program terminated, a researcher released a pair of adult round crucian carp, Carassius buergeri grandoculis (Fig. 3), into a rice paddy and thereby obtained a few tens of thousands of juvenile fish. Based on these preliminary results, Yukiko Kada, who had been the principal researcher of the abovementioned research project, was convinced that fish such as the round crucian carp could still propagate and grow in rice paddies if the paddies were accessible. This fish is an especially important for residents in Shiga Prefecture because it is an endemic subspecies of Lake Biwa, and is designated as endangered in the Environment Ministry's national red list, but is nonetheless a major fishery resource as a principal ingredient in funa-zushi, a specialty food of Shiga (Maehata 2013; Ohtsuka 2014). Dr. Kada persuaded officials of the Department of Agriculture and Fisheries, Shiga Prefecture to undertake a new official project to enhance fish breeding in rice paddies. Preliminary efforts to develop fish passes and to design experiments to confirm the utility of rice paddies as fish nurseries were started in 2001. Soon after, local people in various places around Lake Biwa began to take steps to implement these ideas (Kada 2012). 


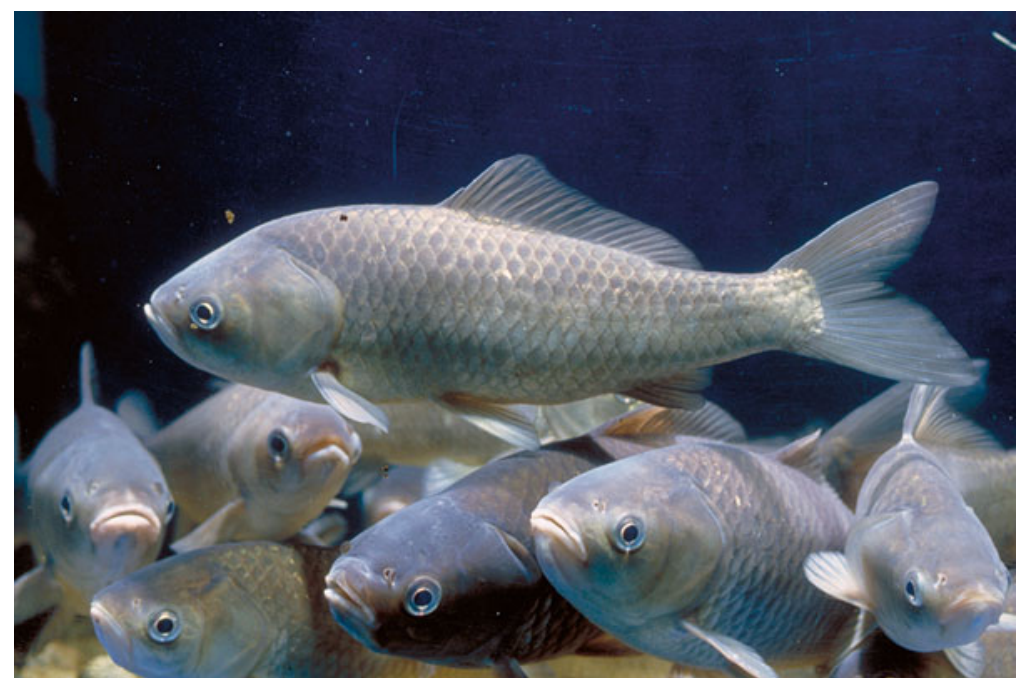

Fig. 3 Round crucian carp, Carassius buergeri grandoculis (CLake Biwa Museum)

There are three important points to note in evaluating the role of the Lake Biwa Museum in this important social innovation. First, the original idea of this project was advanced by a researcher from the museum who relied on testimony concerning personal experiences of farmers around Lake Biwa (Kada 2000, 2012). The idea was probably deemed acceptable by the local communities because it was based on their own experiences. Second, the cooperative response of the communities and local government to the program suggested by the museum appears to have been based on rich social capital (Tanaka 2006). According to the definition offered by the OECD (2007), social capital is "networks together with shared norms, values and understandings that facilitate cooperation within or among groups." In the present case, it may be largely attributable to the regional social characteristics of Shiga Prefecture (Makino and Yang 2010), but the community-based approaches of both the museum researchers and the local government officials contributed to an increase in the social capital in these regions. Third, the museum researchers did not contribute more than the original idea and some related background knowledge during the first few years of the project. Technical development mainly took place at other research establishments, policy formation and implementation was undertaken by officials of the prefecture's Department of Agriculture and Fisheries, and the practices were carried out by local communities (Tanaka 2006). In this case, the orientation of the museum's studies, toward problem-posing rather than problem-solving, was probably conducive to establishing and maintaining this collaboration.

After the "Sakana-no-yurikago-suiden" project was moved into the action phase, the Lake Biwa Museum studied its effects or consequences while also introducing to the communities new researchers from inside or outside the museum who could enhance the program's effectiveness. In addition, some of the museum researchers frequently provided support as lecturers or interpreters to public viewing programs 


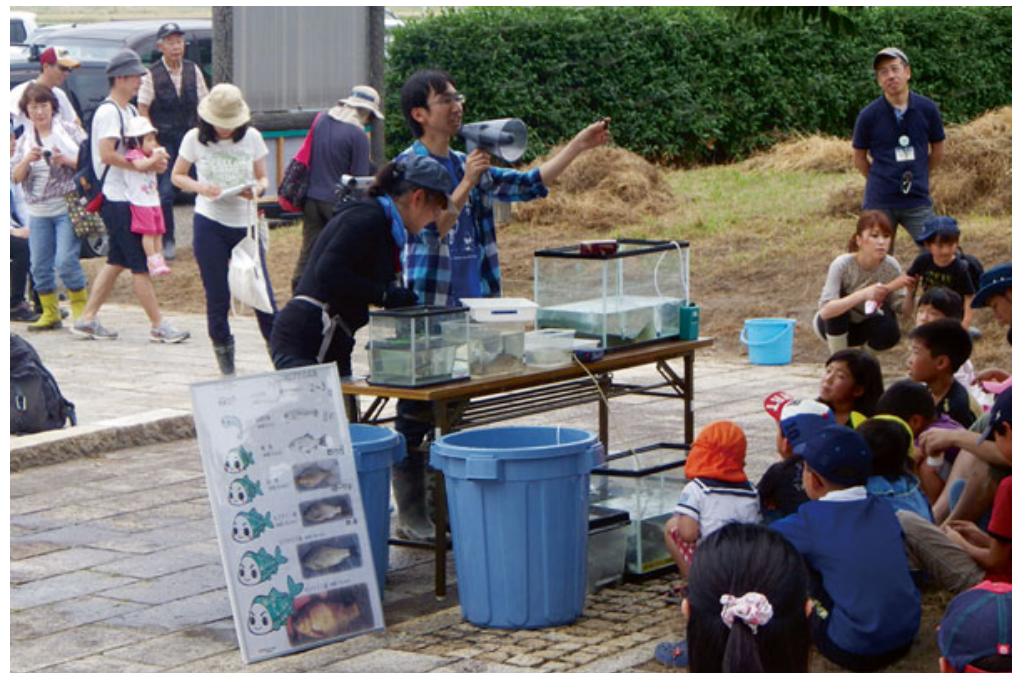

Fig. 4 Museum researchers providing support to public viewing programs

mainly conducted by local farmers' groups and coordinated by officials of the local government (Kanao and Ohtsuka 2013) (Fig. 4). It is hoped that such collaborative and interactive activities including the Lake Biwa Museum among the actors will produce further social innovations that bring a "better relationship of coexistence between humans and lakes" closer to fruition.

Acknowledgement I wish to thank Dr. Mark J. Grygier for his advice including English corrections.

Open Access This chapter is distributed under the terms of the Creative Commons AttributionNonCommercial 4.0 International License (http://creativecommons.org/licenses/by-nc/4.0/), which permits any noncommercial use, duplication, adaptation, distribution and reproduction in any medium or format, as long as you give appropriate credit to the original author(s) and the source, provide a link to the Creative Commons license and indicate if changes were made.

The images or other third party material in this chapter are included in the work's Creative Commons license, unless indicated otherwise in the credit line; if such material is not included in the work's Creative Commons license and the respective action is not permitted by statutory regulation, users will need to obtain permission from the license holder to duplicate, adapt or reproduce the material.

\section{References}

Engeström, Y. 1987. Learning by expanding: An activity-theoretical approach to developmental research. Orienta-Konsultit: Helsinki.

Engeström, Y. 2008. From teams to knots: Activity-theoretical studies of collaboration and learning at work. Cambridge: Cambridge University Press. 
Kada, Y. 2000. Seibutsu-tayousei to bunka no tayousei-Mizube-kankyo no jissenteki-hozen-ron ni mukete [Biodiversity and cultural diversity - Toward a practical methodology for conserving waterfront environments]. In No-san-gyoson to seibutsu-tayousei [Rural villages and biodiversity], ed. T. Udagawa, 134-150. Tokyo: Ie-no-hikari Association. (In Japanese).

Kada, Y. 2001. Chiiki-shakai de no hakubutsukan riyo no jissen-teki tenkai no kanousei-BiwakoHakubutsukan e no raikan ga kenmin ni motarasu hakubutsukan-image kara nani wo tenbo dekiru no ka [Possibility of practical development of museum utilizations in local areas - What can be put in perspective based on the visitors' images of Lake Biwa Museum]. In Shisaku to site no hakubutsukan no jissen-teki hyoka-Biwako-Hakubutsukan no Keizai-teki, Bunka-teki, Shakai-teki kouka no kenkyu [Practical evaluation of a museum as a political measure-Studies of economic, cultural, and social effects of Lake Biwa Museum], ed. Murayama, H. 138-146. Tokyo: Yuzankaku. (In Japanese).

Kada, Y. 2012. Chiji wa nani ga dekiru no ka- "Nihon byou” no chiryou wa chiiki kara [What can a governor do?-Japanese disease is cured in a local area]. Nagoya: Fubaisha. (In Japanese).

Kanao, S., and T. Ohtsuka. 2013. Lake Biwa basin as a venue for paddy field ecosystem studies: The past, present and future. Aquabiology 35: 426-432. (In Japanese with English abstract).

Maehata, M. 2013. Why do cyprinid fishes of Lake Biwa swim up to the paddy fields in the rice planting season? Aquabiology 35: 208-214. (In Japanese with English abstract).

Makino, A., and P. Yang. 2010. Analysis of the social conditions conducive to sustainable organic rice farming around Lake Biwa in Japan. Asian Rural Sociology 4: 284-289.

Nakanishi, M., and T. Sekino. 1997. Recent drastic changes in Lake Biwa. Bio-communities, with special attention to exploitation of the littoral zone. GeoJournal 40: 63-67.

Nunotani, T. 2014. Social duties of the museum for nature conservation. Bulletin of Kansai Organization for Nature Conservation 36: 81-82. (In Japanese).

OECD. 2007. Human capital: How what you know shapes your life. Paris: OECD Publishing.

Ohtsuka, T., K. Iwasaki, A. Kumagai, and T. Konishi. 1996. Decline of the emergent macrophyte zone along the eastern shore of Laka Biwa's South Basin. Japanese Journal of Limnology 57 : 261-266. (In Japanese with English abstract).

Ohtsuka, T. 2014. Nursery Grounds for Round Crucian Carp, Carassius auratus grandoculis, in Rice Paddies around Lake Biwa. In Social-ecological restoration in paddy-dominated landscapes, ed. U. Nishikawa and T. Miyashita, 139-164. Tokyo: Springer.

Shiga Prefecture. 2000. Mother Lake 21 plan. Summary and backgrounds. Shiga Prefecture. http:// www.pref.shiga.lg.jp/biwako/koai/mother21-e/0.pdf. Accessed 10 Feb 2015.

Shiga Prefecture. 2014. Dai 47 kai Shiga kensei seron chosa [47th public opinion poll of Shiga Prefecture]. Otsu: Public Relations Division of Shiga Prefecture. (In Japanese).

Tanaka, S. 2006. "Sakana-no-Yurikago-Suiden" project [Project for "Restoration of Fish Breeding Mechanism in Paddy Fields"]. In Chiiki to kankyo ga yomigaeru suiden saisei [Restoring rice paddy wetland environments and the local sustainable society], ed. I. Washitani, 104-124. Tokyo: Ienohikari Kyokai. (In Japanese).

Yasumuro, T. 2000. No-san-gyoson no minzoku to seibutsu-tayousei [Rural folklore and biodiversity]. In No-san-gyoson to seibutsu-tayousei [Rural villages and biodiversity], ed. T. Udagawa, 134-150. Tokyo: Ie-no-hikari Association. (In Japanese). 